\title{
MORE EFFICIENT TAXATION IN THE RUSSIAN FEDERATION NOWADAYS
}

\author{
K. M. Musaeva*, B. K. Aliev, R. M. Magomedova \\ Dagestan State Unversity, 43 Gadzhiyeva Street 367014 Makhachkala, Dagestan, RF, Bloc-
}

A, Dagestan State University

Published online: 08 August 2017

\begin{abstract}
The study aims to substantiate the theoretical basis and develop give practical advice as to more effective excise taxation in the Russian Federation. The scientific novelty of the study is the set of suggestions and recommendations to balance excising of alcoholic products and improve its administration at all levels of government of the Russian Federation. The study reveals prerequisites for changing excise rates that are the most easily variable element of taxes. It focuses on the alcohol market as one of the most complex and significant excise products markets. The findings of the analytical research serve to support the economic inexpedience of further growth of excises in the modern RF. The most important features of the Russian alcohol market are shown in connection with the consumption structure, counterfeiting of products and state regulation of production of and dealing in alcoholic substances. The alcoholic products experience of developed countries is also studied from the perspective of its possible application to the contemporary Russian realities. To make administration more efficient, the need for long-term solutions integrating the state information system with corporate excise stamping systems. Local problems with low fiscal performance of excises are exemplified by the situation of the Republic of Dagestan. Legislative and organisational suggestions are made to have excises managed more efficiently at the regional level.
\end{abstract}

Keywords: excises, rates, state regulation, governmental control, alcoholic products, alcohol products.

Author Correspondence, e-mail: xaibat27@rambler.ru

doi: http://dx.doi.org/10.4314/jfas.v9i2s.854 


\section{INTRODUCTION}

Traditionally, there are direct and indirect taxes. Direct taxes are known to be the earliest form taken straightly from the taxpayer's property or income. Nevertheless, indirect taxes included in the price of goods or services are widespread. The main advantage of the indirect taxes over direct ones is that the revenue produced by them does not depend on financial performance of the taxpayers and the fiscal performance is guaranteed even if the business is down and out. In present-day RF, one of the key revenues of the federal and local budgets is derived from such indirect taxes as excises, the potential of which is only to be realized. Internationally, excises are interpreted narrowly (individual excises) as well as broadly (universal excises). These concepts include all sales-related taxes such as excises on particular goods and services, VAT, sales tax and custom duties. The narrow interpretation includes only taxes charged as markups on prices of particular goods and services. VAT is rarely regarded as a kind of turnover tax; both are rather attributed to a separate group opposed to individual excises. In the Russian Federation, the term "excise" is used in the narrow sense only (B.Kh. Aliyev [АлиевБ.X.]and Kh. M. Mussayeva [МусаеваX.M.],2013). In Russia, excises are indirect federal taxes charged as markups to the prices of goods. However, un like the VAT, it is the wholecostofa product that bears the tax to include material costs.

Besides the fiscal function, excises are means to avoid threats to the public order. The state indirectly regulates production of alcoholic beverages through consumption by financial disincentives (V.F. Tarassova [TapacoBaB.Ф.], 2017).

The Main Guidelines of the Tax Policy of the Russian Federation for 2017 to 2019, do not provide for any tax reliefs but rather increase tax burden in respect of some taxes to include excises (The Main Guidelines of the Tax Policy of the Russian Federation, 2017 [ОсновныенаправленияналоговойполитикиРФ,2017]). The budget policy of the Russian Federation is once again aimed to increase the tax burden explaining it by the complicated financial situation caused by the persisting sanctions imposed by US and other developed countries. Making excising as one of the most significant fiscal sources more efficient is becoming more important in this situation and makes this study relevant. A better excising is one of the most important preconditions of improvement of the economy, the society and various public budgets.

\section{Research Procedure}

In the Russian Federation since 1 January 2001, the excising procedure is regulated by Chapter 21 of the Tax Code (with later changes and amendments (Tax Code of RF, 2017). Presently, the RF taxation system is undergoing changes although those under way are not so 
fundamental as soon after the Code's adoption. However during recent years, a considerable experience of the tax system formation and development has been gained which enables to analyse trends and dynamics making taxation more fair and efficient.

Changing of excise rates is an important part of this process. It is no coincidence, that excise rates are permanently being reviewed. At the beginning of transition to the market economy (1991), ad valorem (percentage) rates were set for all excisable goods without exemption. This approach avoided frequent indexation of tax rates. Moreover, the rates were applied to the "sale price including the excise" which lowered their real amounts psychologically. However this practice caused some financial and organisational problems. There was an evident imbalance between excising of domestic and imported goods, because the basis for taxation of the latter was determined as their customs cost without excises while the rates were the same for both. Despite the high custom duties foreign producers had a competitive edge over the Russian ones thus demotivating them. Moreover, the Russian experience with the percentage rates showed that they did not protect the state from a partial tax evasion since most of the evasion schemes used not initial profits but those derived from resale. The ad valorem rates also made price balancing more difficult for producers because packaging, advertising and design costs increased excises automatically.

Changing the method of calculation of excise rates as the most variable element of taxation was material for the establishment of excising in RF. Given the aftermath of the ad valorem (percentage) method, the Federal Law of March 7, 1996 introduced excises as indirect taxes charged to the price (Federal Law on Changes to the Law of the Russian Federation on Excises, 1996). Then, percentage excise rates had been cancelled and replaced with specific ones charged as amounts fixed per product units as well as with those combining the percentage and specific components. As a result of this change, import and domestic production had begun to be taxed on equal terms. It is worth noting, that despite a number of obvious advantages of specific rates over percentage ones, they need to be constantly factored by inflation.

According to the effective Russian legislation, producer's retail price differs from its wholesale by indirect taxes such as excise and VAT. The price includes the excise first and then the VAT. This is due to the fact, that the VAT tax base includes the excise as well. Therefore, VAT cannot be included in the price of excisable goods until their prices contain excises. Theoretically, the excise increases the retail price passing the tax burden on to the consumer. However, practically most of the companies take this burden fully or partially to keep their prices competitive. Instead of becoming a part of the retail price, excises increase the cost of production, thus, decreasing the profit. That is what happened to the Russian beer producers and importers. In 
2010, beer excises grew threefold, they covered the difference with their funds. As a result, in 2011, the annual profit of the market totaled 40\% less than in 2009 (T.Yu. Glushko [ГлушкоТ.Ю.], 2015). After that, the brewers had to raise their selling prices shifting the burden on the buyers.

Excise revenues make about $70 \%$ of all income received by the state from the alcoholic sector. Since 2012, excise rates for products containing alcohol have been indexed significantly faster than for other goods and the rate of inflation itself (see. Table 1).

Table 1. Alcoholic Products Excises in Russian Federation 2012 to 2016

\begin{tabular}{|l|c|c|c|c|c|}
\hline Excised goods & \multicolumn{4}{|c|}{ Excise rate, RUR } \\
\cline { 2 - 6 } & Jul. 1,2012 & 2013 & 2014 & 2015 & 2016 \\
\hline Over 9\% (RUR per 1 liter of alcohol in the product) & 300 & 400 & 500 & 600 & 600 \\
\hline Under 9\% (RUR per 1 liter of alcohol in the product) & 270 & 320 & 400 & 500 & 550 \\
\hline Natural wine (RUR per 1 liter) & 6 & 7 & 8 & 9 & 10 \\
\hline Sparkling, gassed, fizzy etc. wines (RUR per 1 litre) & 22 & 24 & 25 & 26 & 27 \\
\hline Beer 0.5 to 8.6\% of alcohol by volume (RUR per 1 litre) & 12 & 15 & 18 & 20 & 21 \\
\hline
\end{tabular}

Source: The Main Guidelines of the Tax Policy of the Russian Federation(2015)

As Table 1 makes clear, Russian alcohol excises vary within broad confines. Another rise has been planned for 2017 - 2019 to be as large as 2 times for wines except for the fizzy ones. It is suggested to broaden the list of excisable goods to include the "electronic cigarettes" (disposable nicotine intake devices). In 2018 , tobacco excise rates will rise by $10 \%$ and $10 \%$ to that amount next year. Class 5 motor gasoline is proposed to be excised at RUR 10,637 per ton in 2018 (compared to RUR 10,130 in 2017) and at RUR 11,062 per ton in 2019.

Should the trend persist, the gap between the value of legal and illegal goods will only broaden. In our opinion, budget revenues will decrease in that event because the high excise growth rates make the illegal dealing profitable decreasing the level of economic security of the country. This conclusion may be confirmed by a mental experiment. All taxpayers show different financial performance. As excises rise, the least effective taxpayers are compelled to cease or go totally illegal. Those performing at medium levels go illegal only with some of their excisable goods and it is only highly-profitable enterprises that would probably pay what is due. This situation enables to determine the dependence of legal production from excise rates. The legal production will be shrinking as fast as large the legal production contributed to by taxpayers with different financial performance is. 
Besides the aforesaid, while rising excises annually at rates significantly exceeding inflation, the Russian legislators shall pay attention to the significant differences in excise rates of Customs Union members. Thus, in Belorussia they make about $80-90 \%$ of the Russian ones while the gap between Russia and Kazakhstan remains substantial despite the recent Kazakh excise rise.

\section{FINDINGS}

Our study have revealed the key reserve to be not in a higher rates but in their better balancing along with the stronger control over the excisable goods sales. Improving excise administration is one of the most important means to ease social tension and replenish the federal and the local budgets.

Alcoholic beverages and other alcohol-containing products have a significant share in Russian excisable goods. The study supports the statement, that passing to drinks with lower alcohol content is one of the best ways to bring the alcohol consumption down. It can be reached by higher excises on stronger beverages. Recently, the Russian government strengthened the regulation of the brewing industry but consumption regulation mechanisms do not work properly. The disproportional growth of beer excises is making stronger drinks consumed more heavily. In Russia, strong beverages make $51 \%$ of total consumption, beer has $38 \%$ of it and only $11 \%$ fall at wine while the distribution $15-50-35 \%$ is considered least harmful for health (A.S. Kondrashova [КондрашоваA.C.], 2014). In 2017, the Russian legislators have to bring the growth of the beer excises in compliance with inflation and try to lower them in the next years. The further disproportionate rise of beer excised will increase the consumer prices and kill demand. Moreover, higher excises encourage illegal production jeopardizing public health and rising healthcare costs. It must be kept in mind, that the share of drinking population is large in Russia which makes a forceful solution with direct bans etc. impossible. Consumers would shift to cheaper surrogates causing the legal alcohol taxation base shrink and illegal employment rise. Unstable and troubled economy the underground sector absorbs social pressure of unemployment by self-organisation of people. "At the same time, informal employment is associated with low productivity, scarce income and other "low-quality" job properties. In reality, there is a close connection between the formal and informal sectors in a down economy where the trend towards the growth of the informal job market brings about the need for the minimal social standards, institutional employment legalisation methods and fighting economic criminalisation in the regions". (M.V. Simonovaetal. [Симонова,М.В.идр.], 2016). 
Thus, the foregoing leads to the conclusion, that excise rates have to be balanced considering the negative consequences of their rise for producers and importers as well as the interests of consumers and the need to protect population and its health.

To assess the efficiency of excises more comprehensively, we analyse their fiscal performance in the particular region of Dagestan. To reveal budget income potential is especially topical for Dagestan due to the low self-sufficiency and scarce financial resources to carry out economic modernization programmes and projects (Kh.M. Mussayeva et al. [МусаеваX.M. идр.], 2016). Presently (2017), 69\% of the Dagestan state budget are subsidies of the federal government.

According to the Federal Tax Service of Russia for Dagestan, in 2015 the republic had collected RUR 27,515.80 mln of taxes making 103.2\% of the previous year. According to Table 2, the total amount had increased by RUR $1,364.40 \mathrm{mln}$ mostly due to the growth of the VAT by RUR 1,470.30 mln or 1.7 times and environmental payments by RUR $168.5 \mathrm{mln}$ or 1.2 times. At the same time, the fiscal share of the excises decreased from $13.2 \%$ to $12.5 \%$ over the same period.

Table 2 . Taxes Collected to the Budget of R Fin Dagestan in 2014 - 2015

\begin{tabular}{|l|l|l|l|l|l|}
\hline & \multicolumn{2}{|l|}{2014} & \multicolumn{2}{l}{2015} & \multirow{2}{*}{ Growth, \% } \\
\cline { 1 - 5 } Taxes and payments & RUR mln & Share, \% & $\begin{array}{l}\text { RUR } \\
\text { mln }\end{array}$ & Share, \% & \\
\hline Total Taxes and payments & $26,662.6$ & 100.0 & $27,512.8$ & 100.0 & 103.2 \\
\hline - to the federal budget of RF & $5,163.1$ & 19.4 & $6,527.5$ & 23.7 & 126.4 \\
\hline - to consolidated budget of RD & $21,499.5$ & 80.6 & $20,985.3$ & 76.3 & 9.6 \\
\hline VAT & $2,121.8$ & 8.0 & $3,592.1$ & 13.1 & 169.3 \\
\hline Corporate income tax & $3,169.6$ & 11.9 & $2,432.1$ &, 8.8 & 76.7 \\
\hline Personal income tax & $11,704.6$ & 43.9 & $11,483.3$ & 41.7 & 98.1 \\
\hline Excises & $3,592.7$ & 13.5 & $3,426.8$ & 12.5 & 95.4 \\
\hline Environmental payments & 829.8 & 3.1 & $1,008.3$ &, 3.7 & 121.5 \\
\hline Corporate property tax & $2,811.2$ & 10.5 & $2,825.4$ & 10.3 & 100.5 \\
\hline Personal property tax & 116,1 & 0.4 & 129.6 &, 0.5 & 111.6 \\
\hline
\end{tabular}

*According to the Report of 1-NM of the Federal Tax Service Administration of Dagestan for 2015

The consolidated budget of Dagestan had received $2.4 \%$ or RUR $513.50 \mathrm{mln}$ less compared to the year 2014 due to the worse performance of the main taxes: personal income tax - by $1.6 \%$ 
(RUR $186.90 \mathrm{mln}$ ), corporate income tax - by 19.4\% (RUR $572.20 \mathrm{mln}$ ), alcohol excises $1.6 \%$ (RUR $28.1 \mathrm{mln})$.

At the same time, Dagestan taxation authorities were trying to tighten control over compliance with the tax regulations in the alcoholic sector. Today, 16 companies dealing in alcohol production and sales pay excises in Dagestan. Alcohol market makes most of the excises collected in the republic. The seat tempts brought RUR 3,426.20 mln more to the budget in 2015 makingonly95.6\%ofthepreviousyear'sfigure. Despite the higher rates, the collection totals slid down by $4.6 \%$ (RUR $164.60 \mathrm{mln}$ ): $7.5 \%$ in respect of the federal budget and $1.6 \%$ in respect of the budget of Dagestan.

Excises went down in 2015 mostly because the alcohol sales did the same (25\% to 2014). The relevant amount underpaid in excises by such major budget revenue generating companies as Derbent Spirits Combine and Kizliar Spirits Plant was RUR $267.60 \mathrm{mln}$. This was due to the lack of consumer buying power, insufficient funds of wholesalers underleveraged due to the recession, a great amount of counterfeit spirits, the need to pay excises proceeding from the shipped volumes whether paid up or not. Producers of alcoholic products have to ship them in advance whereas the relevant excises are already due to the budget.

The analysis of the alcohol production in Dagestan shows, that the economy loses because of the incomplete utilisation production facilities when the real production volumes are hidden in breach of the tax law.

Table 3 . Alcohol Production in Dagestan in 2015 against 2015*

\begin{tabular}{|l|c|c|c|}
\hline \multirow{2}{*}{ Products } & \multicolumn{2}{|c|}{ Production, thousands daL } & \multirow{2}{*}{ 2015/2014, \% } \\
\cline { 2 - 3 } & 2014 & 2015 & \\
\hline Brandy & 644.0 & 636.0 & 97.8 \\
\hline Sparkling wine & $1,159.9$ & $1,012.5$ & 99.4 \\
\hline Still wine & 413.7 & 383.9 & 90.8 \\
\hline Vodka & 108.0 & 101.2 & 91.3 \\
\hline
\end{tabular}

*According to the Federal Tax Service Administration of the Republic of Dagestan for 2014 - 2015

In 2015, the occupancy of the alcohol production facilities in Dagestan was as follows: $7.9 \%$, in respect of vodka, $48.3 \%$ in respect of brandies, $46.1 \%$ in respect of fizzy wine, $22.9 \%$ in respect of still wine. The pure alcohol production facilities had not been used at all, which is indicative of illegal sales. The illegal import of alcoholic products including that which is below the minimal normative prices is a problem for Dagestan. At the same time, the alcoholic products sold in Dagestan are mostly vodka produced mostly outside. The low level of 
wine production can be explained by the insufficient domestic production of grape. Moreover, most of the grape is used to produce sparkling wines. As it appears from Table 3, in 2015 the amount of alcoholic products produced in Dagestan decreased by $5.2 \%$ on average compared to the level of 2014.

Proceeding from the above, one can infer, that only a better use of production and sale facilities can increase the excise budget performance in Dagestan. To do so, the system problem must be solved. Alcohol-producing enterprises do not work due to the absence or a low quality of the raw materials including the fortified wine, which is (in turn) due to a very high cost of its making; the absence of the market; the low quality of the own production caused by the damping from the neighboring regions.

\section{DISCUSSION}

The economic meaning of excises is subject to discussion, although not so bright as the other tax terms. Excise is a kind of indirect tax aimed mainly at muss consumption products such as salt, sugar, matches etc. as well as the public utilities and other widely-demanded services (The Great Soviet Encyclopedia [БольшаяСоветскаяЭнциклопедия],2008). “Anexciseisanindirecttaxona consumer product or service". (S.I. Ozhegov, N.Yu. Shvedova [Ожегов,С. И. иШведова,Н. Ю.],2013)

The explanatory dictionary of V.I. Dahl defines excise as a tax imposed on the domestic consumption, or (in an opposite meaning) a duty, levy or payment to a tax farmer, city or community from any trade or goods (V.I. Dahl [Даль,В.И.], 2006). An excise is levied "in the course of an income or goods, works and services including the price of goods or services to be paid by their consumer". (Т.Yu. Glushko [Глушко,Т. Ю.],2015).

An excise is an indirect tax included in the price of goods or services to be consumed predominantly by a mass consumer, and the services of private enterprises paid up by their consumers.(I.A. Mayburov and Yu.B. Ivanov [МайбуровИ.А. иIvanovЮ.Б.], I.A. andYu.B. Ivanov, 2014).

In the effective Russian tax legislation, excises are a separate kind of taxes differing from the VAT in the following respect: the subject of taxation being only the sales of a particular excisable goods and not the works or services performed by taxpayers being mostly companies or individual entrepreneurs selling the excisable goods produced by themselves, and the base determined as the volume of sold excisable goods in kind, because all the effective excise rates are specific or firm. (S.N. Rukina and I.P. Denissova [Рукина,C.H. иДенисова,И.П.], 2015).Recognising that excise has all principal attributes of a tax (such as 
compulsoriness, individual uncompensability, financing of public and municipal bodies) the author proposes the following definition: Excise is a compulsory, individual and uncompensable payment charged to provide for financial needs of the state and municipalities from companies and individual entrepreneurs in the course of production and in some instances, also from legislatively defined goods and products.

Excises have been used as principal taxes since ancient times. Historical studies show, that some excises were known in the Roman Empire including sales tax, special slave sales tax and the tax on liberation of slaves. Generally, all individual excises in Europe as well as in Russia originate from tax farming - the purchase of the right to collect and sell monopolised goods by a private person.(N.E. Leskova [Лескова,H.E.], 2001).

Excises began to spread widely in Europe in the XVII century and indirect taxation predominated until the XX century. Afterwards, the increased income taxation brought down the fiscal role of the universal and individual excises alike. Nevertheless, individual excises are used by most countries of the world due to their significance to financial resources of the state.

Historically, in Russia excises have played an important fiscal role to include not only conventional alcoholic beverages (vodka, wine) but traditional ones such as quass, beer and mead. "During the WW I, as the prohibition law was adopted, tobacco, matches and kerosene excises were risen sharply to compensate the lack. In the times of the new economic policy there were many excises on tea, coffee, sugar, salt, tobacco, matches, oil products and textiles. (D.G. Chernik and Yu.D. Shmeliov [Черник,Д.Г. иШмелев,Ю.Д.], 2013). However in the following years, excises played no independent role until the return to the market system. "In 1992, excises were restituted during the tax reform as a separate kind of tax payments to the federal taxation system". (M.V. Romanovsky [Романовский, M.B.],O.V. Vrublevsкауа [Врублевская, О.В.], 2009).

By the introduction of Chapter 22 "Excises" to the Tax Code of RF (1 January 2001), the previously used list of excisable goods was amended with crude ethanol, all kinds of mouthpiece cigarettes, diesel fuel, motor oils and motor bikes. During the next years (2002 - 2004) oil and stable gas condensate, natural gas and jewelry were removed from it. In 2007, the list was again supplemented with household chemicals containing alcohol in metal spray cans and alcoholic perfumes in the same package. Later (2012 - 2016), household heating oil, benzene and aircraft motor gasoline were added. (Tax Code of RF [НалоговыйкодексРФ], 2017). In 2016, excises made $9 \%$ of the RF consolidated budget income. In picture 1, they hold the sixth fiscal performance position after the personal income tax, mineral tax, VAT and corpo- 
rate income tax. It is known, that their regulating function is to limit consumption of products harmful to health, to ensure economic security and protect domestic producers in competition with foreign ones.

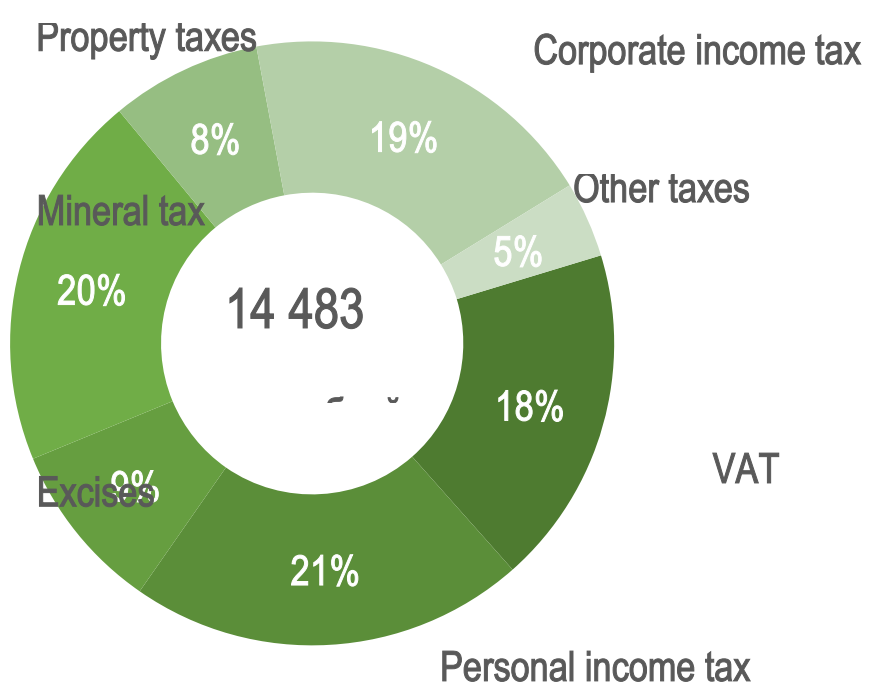

Picture 1. Consolidated Budget Income of the Russian Federation in 2016

Developed countries use different excise rates for different alcoholic products. The highest ones are provided for strong spirits, first of all, in Scandinavia, especially, in Sweden. It is worth noting, that Italia, Luxemburg, Greece, Austria and Portugal emphasise tobacco excising in favour of alcoholic beverages. (Anderson, P., \&Baumberg, B., 2006). In EU, fortified and natural wines are excised at different rates. Moreover, "it is legally prohibited to fortify wines with ethyl alcohol, and they use only grape alcohol for that". (P.O. Korneychuk [Корнейчук,П.О.],2014).

Since excises differ for different alcoholic drinks, the EU has socially adequate alcohol production and consumption. (T.K. Podgornaya [Подгорная, Т.К.],2005). This approach restrains production of some beverages and favours the others. A zero rate for natural grape wines - still as well as sparkling - is indicative of that.

EU uses lower rates for low-alcohol beer and dry wines. The general rule in respect of beer is that they may not be less than $50 \%$ of the principal rate. As regards wine, the rates depend on national peculiarities (European Community's Council Directive 92/83/EEC, 1992).Forexample, the big producers of sparkling winessuc has Greece, Spain, Cyprus, Italy, Portugal and Slovenia do not exciseitatall (N.P. Kucheriavenko [Кучерявенко,Н.П.], 2003). 
One of the "best-known methods of state intervention in alcohol trade is the public monopoly which may vary in respect of its scale and scope pursuing different goals". (T. Ugland [Угланд, Т.], 2000).Thus, some countries monopolies production of some spirits by licensing. Usually, private licenses are given to produce beer while strong spirits production is controlled by the state. In Norway, the monopoly has been abolished. (Taxations Trends in the European Union Data for the EU Member States, Iceland and Norway,2016). At the same time, in Northern Europe as well as in US and Canada there is a state monopoly for trading in alcoholic drinks which has been efficient at moderation of alcohol-induced problems.

The peculiarities of excises in foreign countries suggest the need to continue their optimisation in Russia. However, European practices shall be implemented prudently and consistently.

The comparison of the alcohol production in Russia and developed countries revealed a great number of players with multiple brands. Since it is hard for a consumer to make sense of all this diversity, none of them dominates the market. According to the experience of developed countries, the producers have to finally consolidate. (TaxationsTrendsintheEuropeanUnionCommunities,2008).

Currently, the growth of alcohol consumption in Russia is rather a problem. Immoderate drinking has various medical and social consequences and is responsible for many health problems of Russian people. "According to the WHO, alcohol abuse is the third major cause of death next to the cardio-vascular and oncology diseases. Some scientists believe, that "such a high morbidity and death rate is due not only to abuse itself but to the unavailability of quality drinks to the masses of poor population". (Ye.I. Vlassiuk [Власюк,Е.И.], 2017).

Illegal sales of excisable goods is an important problem of the present-day Russia which has to be solved comprehensively and systematically. Alcoholic products are falsified everywhere in the world but the scale of this falsification in Russia is especially large. According to different data, counterfeit products make 40 to $50 \%$ of the market. (T.Yu. Glushko [Глушко,Т.Ю.], 2015). It is due to the inefficient governmental control in that sphere along with the lack of cheap alcoholic drinks because of the excise rates are high and their certification is complicated.

In the modern Russia, one of the ways to evade excise payments is the so called "alcoholcontaining scheme". The producers use alcohol-containing products instead of pure ethanol contradictory to all and any legal production norms. The reason is, that excise payers may 
decrease excises payable on their products by excises paid on excisable goods used as raw materials. Therefore, the imperfect legal base incites various excise evasion schemes.

To better control the alcohol sale chains, the Unified State Automated Information System (USAIS) was introduced in Russia. The system is meant to provide for automated accounting in control of the information about production and sales of alcoholic beverages and alcoholcontaining products. It is topical for the alcohol market players to integrate their information systems with USAIS. Having to input data in the unified system, Russian companies have to do extra work, avoid duplications, permanently check information for compliance with the USAIS. This problem also must be solved at the governmental level in a scheduled way.

\section{CONCLUSION}

The main conclusions and suggestions of this study are as follows.

1. Excises have been growing in the Russian Federation steadily and faster than inflation. For 2017 to 2019, further growth has been planned. Should the trend persist, the gap between prices of legal and illegal products would widen while the budget performance of excises would decline since their high growth rates would favour illegal sales and jeopardise the country's economy.

2. Due to the high earning capacity of excisable production, taxable businesses are especially inclined to evade. The main goal of the fiscal authorities is then to control the market in a way protecting it from the bad faith entrepreneurs evading excise payment and competition. Therefore, special governmental controls should be introduced in respect of excisable goods and, especially, alcoholic products. The state regulation of the alcohol-producing sector is a complex task depending on many factors such as the country's taxation and social policy, the role of the state in the alcohol market, the efficacy of interaction between the government and the business.

3. In the Russian Federation, the main potential of the budget performance of excises is not to rise but to balance them and improve tax management and sales control. Better tax management is an important to improve the economic and social situation as well as to fill up the budgets. To fight the "alcohol-containing scheme", excises calculation and payment methods should be specified by stating that excises payable on acquisition of excisable goods used as raw materials are deductible only when the use of such raw materials is explicitly provided by the Russian state standards (GOSTs), technical conditions (TUs), recipes and other technical norms. 
4. To simplify control over the excisable products flow, software solutions should be developed to integrate the Unified State Automated Information System (USAIS) with corporate information networks planning purchases and excise label supply. Such software may register production, supply and sales of excisable products and check supporting documents for correct excise labels.

5. Alcoholic production excising being a significant source of the budget income shall be reformed considering the experience of the developed countries. To do so, it is expedient, first, to change the rules of excising with excise labels by making them the sole method of payment of the full amount due as taxes; second, to set higher excise rates for strong spirits and lower rates for low-alcohol drinks while stopping to rise rates for all excisable products equally and faster than inflation; third, to consolidate alcohol brands.

6. To rise efficiency of the alcoholic production and collectability of excises in Dagestan, shipments of alcoholic products should not custom cleared without confirmation of the legality of relevant companies' activities given by custom authorities and relevant alcohol sales license. Secondary winemaking businesses should be assisted with raw materials supplies from other regions of RF and abroad to ensure the full utilization of their production capacity. It will increase the taxation base of not only indirect taxes (such as the VAT) but of the direct ones (income and property taxes). The interdepartmental interaction should be increased as well in respect of the market control. All these measures should be carried out along with adoption of new legal acts regulating excising as well as with other actions to cope with the continuing recession in Russia.

7. Summarizing the aforesaid, it should be noted that some aspects of calculation and collection of the excises are not covered by this study which due to the multiple peculiarities of excising various product groups that are worth independent research. Further studies may be devoted to excising of tobaccos, oil product, cars and other excisable goods as regarded by the Tax Code of the Russian Federation and other states.

\section{BIBLIOGRAPHY}

1. Tax Code of the Russian Federation [Nalogovyy Kodeks Rossiyskoy Federatsii] (2017). Elektronnyy resurs. skachat-nk-rf . Da-ta obrashcheniya:21.03.2017.

2. Federal Law on Changes to the Law of the Russian Federation on Excises [Federalnyy zakon «O vnesenii izmeneniy v Zakon Rossiyskoy Federatsii “Ob aktsizakh”] ot 07.03.1996, (1996) .// Rossiyskaya gazeta. No. 48. 
3. The Main Guidlines of the Tax Policy of the Russian Federation for 2015 and Prospected Period of 2016 to 2017 [Osnovnyye napravleniya nalogovoy politiki Rossiyskoy Federatsii na 2015 god i na planovyy period 2016 i 2017 godov] (2015) document/cons_doc_LAW_126727/. Data obrashcheniya:19.02.2017.

4. The Main Guidlines of the Tax Policy of the Russian Federation for 2017 and Prospected Period of 2018 to 2019 [Osnovnyye napravleniya nalogovoy politiki RF na 2017 g. i na planovyy period 2018 i 2019 godov] (2017). http://minfin.ru. Data obrashcheniya:23.07.2017.

5. Aliyev, B.Kh., Musayeva, Kh.M., (2013) Tax Systems of the Foreign Countries [Nalogovyye sistemy zarubezhnykh stran] - M.: YUNITI - DANA: 42.

6. Anderson, P., \& Baumberg, B. (2006). Alcohol in Europe. A public health perspective. A report from the European Commission. London: Institute of Alcohol Studies:446.

7. The Great Soviet Encyclopedia [Bolshaya Sovetskaya Entsiklopediya] (2008). 3izdaniye - M.: Eksmo: 1482.

8. Vlasyuk, Ye.I., (2017) Some Topical Problems of State Regulation of the Alcoholic Sector in Russia [Nekotoryye aktualnyye problemy gosudarstvennogo regulirovaniya alkogolnoy otrasli v Rossii] // Fundamental and Applied Studies in the Modern World [Fundamentalnyye i prikladnyye issledovaniya v sovre-mennom mire] No. 17: 79.

9. Glushko T.Yu., (2015) Improvement of Sales Management Procedures in the Market of Excisable Products [Sovershenstvovaniye protsessov upravleniya zakupkami na rynke podaktsiznoy produktsii] / Doctoral Thesis [Dissertatsiya na soiskaniye uchenoy stepeni kandidata ekonomicheskikh nauk] 77-88.

10. Dahl V.I., (2006) Explanatory Dictionary of the Current Great-Russian Language [Tolkovyy slovar zhivogo velikorusskogo yazyka] V 4-kh tomakh. Tom 1: A - Z:123.

11. European Community's Council Directive 92/83/EEC [Direktiva Soveta Yevropeyskikh soobshchestv 92/83/YEES ot 19 oktyabrya 1992 o garmonizatsii struktury aktsiznykh nalogov na alkogol i alkogolnyye napitki] (1992) EU Official Bulletin [Ofitsialnyy Byulleten Yevropeyskikh Soobshchestv]No. L 316/31.

12. Kondrashova, A.S., (2014) Is the Excise Rise Reasonable [Schitat li obosnovannym povysheniye stavok aktsizov] // Molodoy uchenyy No. 8.2.: 27-29.

13. Korneychuk, P.O., (2014) World Experience in Alcoholic Products Taxation[Mirovoy opyt nalogooblozheniya alkogolnoy produktsii]//Vestnik Universiteta (GUU). \# 11.: 109-144. 14. Kucheryavenko, N.P., (2003) Fundamentals of Tax Law [Osnovy nalogovogo prava] 2-ye izd., pererab. i dop. - Kharkov, Legas: 302. 
15. Leskova, N.Ye. (2001) Excising: a Retrospective[Aktsiznoye oblozheniye: retrospektivnyy vzglyad] // Finansy, \#4: 67.

16. Mayburov, I.A. and Yu.B. Ivanov, (2014) Taxes and Taxation. The Color Palette of the Con-temporary Problems. - Moscow: Unity-Dana: 299-300.

17. Musaeva, Kh.M., Remikhanova, D.A., Arslanbekova, A.Z., Alieva, E. B., (2016). Shadow Economy and Possible Ways to Decrease It as a Factor of Increasing Tax Revenues in the Budgetary System of the Russian Federation.// International Journal of Applied Business and Economic Research (I J A B E R), Vol. 14, No. 10: 7325-7339.

18. Ozhegov S.I., Shvedova N. YU. , (2013) Explanatory Dictionary of the Russian Language [Tolkovyy slovar russkogo yazyka] - M.: A TEMP: 344.

19. Podgornaya, T.K. (2005). Zarubezhnyy opyt: aktsizy v nalogovoy sisteme Shvetsii // Rossiyskiy nalogovyy kuryer. \#10: 144

20. Romanovskiy, M.V., Vrublevskaya, O.V. (2009) Taxes and Taxation [Nalogi i nalogooblozheniye] - Spb, Piter: 213.

21. Rukina, S.N., Denisova, I.P., (2015). Development of Excising in Russian Federation. In the collection of works entitled Topical Ways of Development of Accounting, Taxation and Statistics in the Innovation-oriented Economy. Materials of the IV International Academic and Research Conference[Razvitiye aktsiznogo nalogooblozheniya v Rossiyskoy Federatsii. V sb.: Aktualnyye napravleniya razvitiya bukhgalterskogo ucheta, nalogooblozheniya i statistiki v innovatsionno-oriyentirovannoy ekonomike. Materialy IV Mezhdunarodnoy nauchno-prakticheskoy konferentsii] - Rostov-n/D, 215: 529-532.

22. Simonova, M.V., Sankova, L.V., Mirzabalaeva, F.I., Shchipanova, D.Ye. \& Dorozhkin, V.E., (2016) Assessment Problems and Ensuring of Decent Work in the Russian Regions.// International Journal of Environmental and Science Education. VOL.11, No. 15: 7608-7626.

23. Tarasova, V.F., (2016) Taxes and Taxation [Nalogi i nalogooblozheniye] - M., KNORUS: 496.

24. Taxations Trends in the European Union. Data for the EU Member States and Norway, (2008). - European Communities, 2008: 447.

25. Taxations Trends in the European Union. Data for the EU Member States, Iceland and Norway (2016). European Union, 2016: 370.

26. Ugland T. (2000) The State Alcohol Monopoly [Gosudarstvennaya monopoliya na alkogol] / Alcoholic Policy in Russia and Norway [Alkogolnaya politika v Ros-sii i Norvegii] - Moskva. - Oslo: 230. 
27. Chernik D.G., Shmelev, D.Yu., (2013) Taxes and Taxation[Nalogi i nalogooblozheniye] - M., Yurayt : 57.

28. Official Data of the Federal Tax Service of Russia [Ofitsialnyye dannyye Federalnoy nalogovoy sluzhby Rossii] (2017) http://www.nalog.ru Search date:3.07.2017.

29. Reporting Data of the Federal Tax Service Administration of the Republic of Dagestan [Otchetnyye dannyye UFNS Rossii po Respublike Dagestan] (2017)http://www.nalog.ru Search date:1.08.2017.

\section{How to cite this article:}

Musaeva K M, Aliev B K, Magomedova R M. More efficient taxation in the Russian federation nowadays. J. Fundam. Appl. Sci., 2017, 9(2S), 1468-1483. 